\title{
DISPOSAL OR TREATMENT: FUTURE CONSIDERATIONS FOR SOLID WASTE FROM THE CONSTRUCTION AND DEMOLITION INDUSTRY
}

\author{
SHANNON L. WALLIS ${ }^{1,2}$, CHARLES LEMCKERT ${ }^{1}$, ROBYN HARDY $^{1} \&$ TERRI-ANN BERRY ${ }^{2}$ \\ ${ }^{1}$ University of Canberra, Australia \\ ${ }^{2}$ Unitec Institute of Technology, New Zealand
}

\begin{abstract}
Each year more than 2 billion tonnes of municipal solid waste are produced globally. The greatest worldwide users of resources in terms of raw materials and energy are from the construction sector. Construction, demolition and excavation waste accounts for a large share of municipal waste and the majority of this waste goes to landfill. Worldwide, the proportion of landfilled construction, demolition and excavation waste compared with the total amount of waste is variable from $13 \%$ to $60 \%+$. Many developed countries are now facing issues with land capacity and are less flexible in their approach to solid waste treatment. New Zealand is a relatively young and geographically isolated country with enough available land to be able to trial new options for waste treatment and currently has seven different types of landfills, including construction and demolition and cleanfill options. Biodegradable substances can be treated via processes such as composting and anaerobic digestion, but substances which are either hazardous or inorganic in structure are generally considered to be untreatable and therefore reduce practical options to landfill or incineration. As any potential treatment in landfills is limited by less than optimal environmental conditions, their primary purpose is simply to hold and isolate waste. Incineration has high energy costs and does not support a low carbon economy. As neither of these options present an ideal long-term solution to solve this waste problem, this paper will consider sustainable options for the disposal and treatment of construction, demolition and excavation waste with a focus on hazardous materials. It will consider New Zealand as a potential case study location for trialling solid waste treatment options whilst discussing waste issues in other countries such as Australia, the United Kingdom and the United States of America. It will also identify barriers which may prevent the treatment of solid waste including considerations for protecting public health and safety.
\end{abstract}

Keywords: waste management, waste disposal, waste treatment, CD\&E waste, hazardous waste.

\section{INTRODUCTION}

Worldwide, more than two billion tonnes of municipal solid waste (MSW) are produced annually [1], where the construction sector is the largest global user of raw material and energy resources [2]. Construction, demolition and excavation (CD\&E) waste contributes to a large share of the total MSW in developed countries [2]. Typically, construction and demolition (C\&D) wastes are defined by activity [3] and consist of relatively inert materials such as concrete and bricks.

The average proportion of total waste reaching landfills which is derived from CD\&E waste is $30 \%$ [4] although this proportion varies globally from $13 \%$ [5] to $60 \%+$ [6], [7]. In $2016,61 \%$ of waste generated in the UK was classified as CD\&E waste [6] whereas Australia reported 31\% CD\&E waste [8] (Table 1). In Hungary, 23\% of waste was labelled as CD\&E [9] whereas Romania reported no CD\&E waste [9]. This could be due to individual countries either not reporting their figures or simply not having the separate CD\&E waste stream but does demonstrate a lack of certainty around this data globally. Although the United Nations Environmental Programme (UNEP) [2] reported that the bulk of waste disposed via landfills 
Table 1: Waste generation and breakdown of waste in seven countries [5]-[10].

\begin{tabular}{lccccccc}
\hline Country & Year & $\begin{array}{c}\text { Total } \\
\text { mass }\end{array}$ & $\begin{array}{c}\text { Waste } \\
\text { generation } \\
\text { per capita } \\
(2015)\end{array}$ & CD\&E & Household & C\&I** & Others \\
\hline UK [6] & 2016 & 222.9 & 1.8 & $61 \%$ & $12 \%$ & $19 \%$ & $8 \%$ \\
\hline Australia [8] & 2016 & 66.8 & 2.2 & $31 \%$ & $21 \%$ & $31 \%$ & $18 \%$ \\
\hline Germany [7] & 2015 & 351.2 & 2.1 & $60 \%$ & $15 \%$ & $17 \%$ & $9 \%$ \\
\hline Japan [10] & 2011 & 380 & - & $20 \%$ & $11 \% *$ & $63 \%$ & $6 \%$ \\
\hline South Africa [5] & 2017 & 42.7 & 2 & $13 \%$ & $20 \%$ & $7 \%$ & $60 \%$ \\
\hline Hungary [9] & 2016 & 16 & - & $23 \%$ & $18 \%$ & $34 \%$ & $25 \%$ \\
\hline Romania [9] & 2016 & 178 & - & $0 \%$ & $2 \%$ & $95 \%$ & $3 \%$ \\
\hline Rom:
\end{tabular}

Notes: Total and waste generation per capita as million tonnes. *Food, paper products and communication devices only. ${ }^{* *} \mathrm{C} \& \mathrm{I}$ include commercial and industrial, as well as agricultural and energy generation sectors.

was derived from CD\&E waste in developing countries, this has not been supported by other research (as demonstrated in Table 1).

Regardless of the reliability of the CD\&E waste data, the vast scale of the problem is concerning and other options to landfill disposal need to be investigated. Established waste disposal and treatment processes for MSW include composting, incineration, landfill and recycling, globally, technology choice is based predominantly on land space availability. In terms of CD\&E waste, previous research indicates a high potential for recovery [5], [7], [8] (with the highest rate available in the absence of hazardous waste (UK) [6]). In New Zealand (NZ), it is possible to recycle and/or reuse most streams of C\&D waste. For example, Green Gorilla, a waste management company in NZ recycles timber, non-ferrous metals, cardboard, plasterboard, steel, rocks and concrete. However, there are other barriers preventing effective recycling or reuse which include a lack of training and education to encourage on-site waste separation, space limitations on site for adequate materials storage and a clear lack of incentives to reduce waste. For hazardous CD\&E derived wastes, recycling or reusing waste is rarely if ever a viable option. So, despite impressive improvements in the capability to be able to divert this waste stream from landfill, this disposal route remains the most common option, globally.

The NZ government defines hazardous waste as that which "contains hazardous substances at sufficient concentrations to exceed the minimum degrees of hazard specified by Hazardous Substances Regulations 2000" or meets the definitions for infectious substances or radioactive materials [11]. The hazardous characteristics that form the basis for these criteria include explosiveness, flammability, capacity to oxidise, toxicity, corrosiveness or eco-toxicity [11]. The lack of hazardous waste management in NZ was identified as a key issue twenty years ago [12] and yet the NZ Waste Strategy (2010) gives little or no mention to hazardous waste disposal [13]. Furthermore, there has been little focus on hazardous wastes which are created due to past activities such as the large quantities of contaminated land which currently follow a similar hazardous waste disposal protocol.

Globally, we produce 400 million tonnes of hazardous waste each year [14]. However hazardous waste from the CD\&E sector consists of three distinct types which should be considered separately. These include, hazardous products (HP) used during construction, e.g. paints and solvents, which are often in liquid form. Hazardous waste (HW) by which we are referring to hazardous components of building products for example, fluorescent lamps containing mercury or electrical components containing polychlorinated biphenyls (PCBs). 
Finally, hazardous by-products (HBP) which are often solid wastes containing a low concentration of hazardous component, such as asbestos or lead contaminated soils. In fact, contaminated soil waste and asbestos waste contributes a significant portion of low concentration, high volume waste to landfill. A previous study quantified the C\&D waste materials in all states across Australia (2008-2009) where 1,055,797 tonnes of contaminated soil waste and 728,477 tonnes of asbestos waste were generated [15].

Lack of available land is becoming an increasing issue for many developed countries reducing flexibility in terms of future solid waste treatment. Are there other options for the disposal of CD\&E waste? And, do these options include more sustainable waste treatment? This paper will investigate the current options available whilst highlighting the issues associated with long-term landfill disposal of hazardous substances.

\section{LANDFILL DISPOSAL}

Modern landfills are designed to minimise the impact of MSW on the environment and human health, providing storage but requiring land-use restrictions and continuing maintenance [16]. Landfills are the most common method of waste disposal in NZ, with an estimated 3.2 million tonnes of waste to MSW landfills in 2006 [17], [18]. This waste typically includes $28 \%$ organics, $16 \%$ rubble, $11 \%$ timber, $8 \%$ plastics, $7 \%$ paper and less than $5 \%$ of glass, metals, and textiles [19]. In NZ, there are currently seven different types of landfills where waste can be disposed; five non-hazardous landfills (MSW, managed, C\&D, cleanfill, industrial) [20] and two hazardous landfills (Class A, Class B) [21]. Cleanfills are defined in NZ as, "material that when buried will have no adverse effect on people or the environment" (e.g. clay, brick, concrete etc.) [20].

From 1995 to 2007, the number of landfills in NZ reduced from 327 to 60 , (often as a result of less than optimal environmental controls), with just 54\% utilising engineered liners for leachate containment [18]. Nevertheless, the amount of waste to landfill in NZ appears to be increasing, rising to just over 1 tonne/capita/yr [22], representing close to 5 million tonnes of waste per annum. It has been estimated that $26 \%$ of waste to landfill is derived from C\&D waste [23]. However, this value does not include waste that is sent to cleanfill sites which was estimated to be between 2.7 and 3.7 million tonnes in 2007 [23].

For hazardous substances, Class A landfills have engineered systems designed to the Centre for Advanced Engineering's Landfill Guidelines (2000), in comparison, Class B landfills are existing landfills that do not meet this guideline, and have little to no engineered systems [21]. Despite landfills specific for hazardous waste, it is estimated that approximately $14 \%$ of waste to four MSW landfills was deemed potentially hazardous [19].

Although there is currently a heavy reliance on waste disposal via landfill, NZ is a relatively young country with a small population and could investigate alternative options for the treatment of CD\&E and associated hazardous wastes. This would be advantageous to support its reputation as an environmentally focused society and to provide a more sustainable option to protect future generations and a fast-growing population.

\section{THE FUTURE OF LANDFILL TECHNOLOGY}

There is evidence to suggest that the world has reached a level of stagnation with respect to landfill design and waste disposal. In 1995, a seminar in the United States was called to examine "an alternative approach to landfill operation that greatly minimizes long-term risks associated with potential landfill containment system failure" [24]. This alternative approach was bioreactor landfilling and it was stated that "this method represents the future of waste disposal because it transforms waste disposal practice from a passive system to an active process" [24]. In 2000, NZ revised their Centre for Advanced Engineering Landfill 
Engineering Guidelines (1992), now called Landfill Guidelines (2000) [25]. These guidelines stated, "bioreactor and aerobic landfills have not been designed or operated in New Zealand to date", however it was stressed that overseas research and trials should be monitored for their applicability to NZ (e.g. bioreactor landfills) [25]). The Landfill Guidelines (2000) were superseded in 2016 (with a further revision in 2018) to Technical Guidelines for Disposal to Land (August 2018), with no reference to bioreactor landfills [26]. Which shows little progress made in terms of landfill design in 25 years.

Current landfill designs and management have a number of issues including a poor level of degradation of waste and issues associated with leachate toxicity due to increased chemical use [27]. Traditional landfills have a large land requirement, and with a growing global population, land space is at a premium. In addition to this, there is a trend towards increasing disposal costs for hazardous waste disposal, which in turn is encouraging illegal dumping of waste [28]; an issue which has been forewarned for New Zealanders over 35 years previously [29].

Issues with landfill failures are widespread despite apparent engineering developments. In the late 1980s problems began to arise for the community of Oakland County Waterford Township (US) in the form of groundwater contamination [30]. It is unclear whether the failure was a result of leachate collection and removal or liner fault [30]; however, it is clear that at the time of landfill construction, guidelines and regulations were less stringent than today. In developing countries, the regulations regarding landfill design are not as well controlled, which has contributed to many landfill failures (Table 2).

Table 2: Worldwide landfill failures [31]-[38].

\begin{tabular}{|c|c|c|c|}
\hline Location & Date & Cause & Fatalities \\
\hline $\begin{array}{l}\text { Payatas, Manila, } \\
\text { Philippines [31] }\end{array}$ & Jul. 2000 & $\begin{array}{l}\text { Heavy rain triggering } \\
\text { landslides }\end{array}$ & More than 200 \\
\hline $\begin{array}{l}\text { Leuwigajah, Java, } \\
\text { Indonesia [32] }\end{array}$ & Feb. 2005 & $\begin{array}{l}\text { Explosion due to sudden } \\
\text { biogas release, } 3 \text { days of } \\
\text { high rainfall }\end{array}$ & Approx. 143 \\
\hline $\begin{array}{l}\text { Morro do Bumba, Niteroi, } \\
\text { Brazil [33] }\end{array}$ & Apr. 2010 & $\begin{array}{l}\text { Heavy rain triggering } \\
\text { floods and landslides }\end{array}$ & $\begin{array}{l}\text { Approx. } 200 \\
\text { (across the } \\
\text { region) }\end{array}$ \\
\hline Baguio, Philippines [34] & Aug. 2011 & $\begin{array}{l}\text { Typhoon - collapse of } \\
\text { retaining wall }\end{array}$ & 5 \\
\hline $\begin{array}{l}\text { Guatemala City, } \\
\text { Guatemala [35] }\end{array}$ & Apr. 2016 & Heavy rain & Approx. 30 \\
\hline Koshe, Ethiopia [36] & Mar. 2017 & Conflicting reasons & Approx. 120 \\
\hline $\begin{array}{l}\text { Meethotamulla Garbage } \\
\text { Mountain, Sri Lanka [37] }\end{array}$ & Apr. 2017 & $\begin{array}{l}\text { Instability - approx. } 48.5 \mathrm{~m} \\
\text { high pre-collapse }\end{array}$ & Approx. 40 \\
\hline $\begin{array}{l}\text { Verter Recycling Landfill, } \\
\text { Basque Region, Spain [38] }\end{array}$ & Feb. 2020 & $\begin{array}{l}\text { Instability - with asbestos } \\
\text { waste release }\end{array}$ & 2 \\
\hline
\end{tabular}

In the past, an acceptable disposal route for hazardous or "special" waste was selected to reduce the possibility of future problems arising from the disposal process [29]. At this time, observations from UK landfills informed that "sensible landfill is realistic and an ultracautious approach to landfill of hazardous waste is unjustified" [29]. However, we have observed since then that there is an increased risk to the public when landfills fail, as there is always a possibility that hazardous substances could be exposed. Landfill failures can happen 
at any time and in any country as evidenced by the landfill failure along the Fox River of NZ's West Coast, where asbestos and hazardous substances were suspected to have been among the strewn rubbish [39]. Even if landfills have not failed yet, there is the risk of collapse, such as Kettle Park in Dunedin, NZ, where large swells are impacting and washing away the protective dunes [40]. Along the coasts of England and Wales, 1,000 historic landfills are at risk of failure by erosion, posing a substantial risk to the local populations [41], [42]. This includes the former landfill in East Tilbury that has been leaking waste and hazardous substances into the Thames River [42]. Landfill failures are not limited to waste discharge but can also include gas leaks, such as the methane leak from Sunshine Landfills in Melbourne, Australia [43]. Failures of historic, recently closed, and active landfills is a trend that could become more frequent as landfills are exposed to more extreme weather events combined with poor siting and lack of adequate regulation. Whilst landfills provide public health protection in the short-term, they can still pose a long-term risk made worse by environmental and human-derived change on climate and land-use.

\section{TREATMENT OPTIONS}

\subsection{Chemical and physical processes}

Chemical transformation processes have potential to reduce toxicity prior to further treatment or disposal. This type of process is often expensive and by-products may be hazardous themselves and pose a further risk. Chemical methods include complexation, neutralisation and oxidation [44] whereas physical processes include complete thermal destruction (incineration) as well the removal of substances from aqueous solution via processes such as carbon adsorption. For hazardous substances, these may include pre-treatment or predisposal stages which can often involve high energy costs. There are a number of other disadvantages associated with these processes including waste production (often toxic), high energy usage and a lack of adaption to wastes of highly variable quality. Similarly, incineration has high energy costs and may not be sustained long-term within a low carbon economy. It is also responsible for the production of air pollutants such as dioxins (unless well-maintained) and highly toxic by-products (such as incinerator ash).

Physical and chemical processes can treat the majority (if not all) of the waste flow and may be useful for pre-treatment however they do not currently provide a sustainable longterm option.

\subsection{Biological processes}

Biological processes have been slow to adopt partly due to limitations on substances resistant to biodegradation, however recent developments support further investigation. Readily biodegradable substances can be treated via biological processes however substances which are either hazardous or inorganic are generally considered to be untreatable. If waste can be considered to exist along a continuum which describes ease of treatment, where inorganic (e.g. hazardous) substances lie at the extreme end (Fig. 1), there is evidence to suggest that treatment has potential even for the most recalcitrant substances, such as asbestos fibres within a cement matrix [45]. The degradation times for some substances are known and in the case of simple and complex organic molecules, this timescale varies depending upon molecular weight and chemical characteristics such as polarity and microbial toxicity.

The treatment of solid wastes remains problematic however bioremediation (biological process) is capable of treating both solid and liquid wastes. Bioremediation can be either in- 


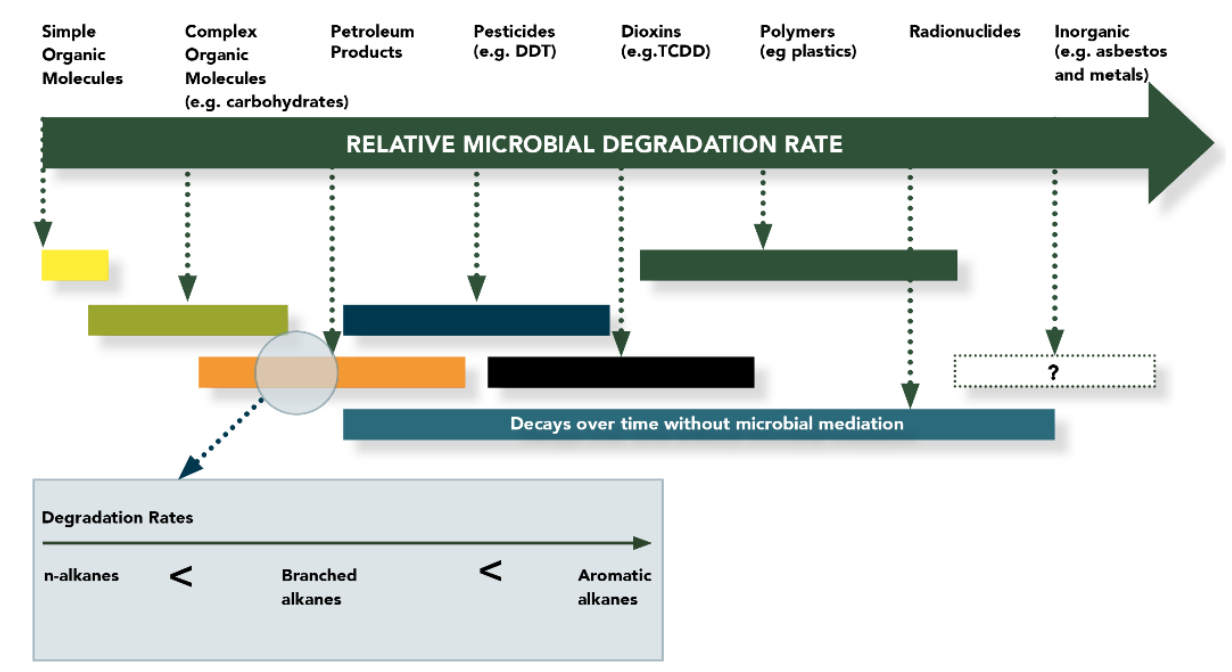

Figure 1: Continuum of relative microbial degradation rate, where length of bar indicates relative degradation timeframe. (Degradation rates of petroleum products [47].)

situ, (bioventing and bioaugmentation); or ex-situ (landfarming and bioreactors (slurry reactors)) [46]. In-situ treatment options are more desirable as they tend to be lower cost and provide less disturbance by treating in place, whereas ex-situ bioremediation involves the excavation of the contaminated soils from the ground and transferred to a separate location for treatment [46]. An example of an ex-situ, partial bioremediation process is the bioreactor (or activated) landfill.

\subsubsection{Bioreactor landfills}

Bioremediation has been trialled on a limited scale within a landfill-type enclosure, called a bioreactor (or activated) landfill, defined where "liquid or air is injected in a controlled fashion to the waste mass in order to accelerate or enhance biostabilisation of the waste" [44]. These reactors are primarily for organic wastes and are designed and operated under conditions to enhance biodegradation and biogas production. Within bioreactors, ambient moisture levels are critical (as microbial growth is enhanced at moisture contents greater than $40 \%$ by weight) so this typically involves the addition of moisture to the process [48]. The addition of moisture serves two purposes, firstly, the creation of conditions favourable for the transport and proliferation of the microbial community and secondly, provides a pathway for mixing organic substrates, nutrients and waste products [48] and the dilution of high concentrations of microbial inhibitors. However, it has been observed that continuously achieving the target moisture content in a landfill is rarely achieved by leachate recirculation alone.

Furthermore, bioreactor landfilling is the least promising option for many wastes (including wood, textiles and paper), based on their estimates of biogas production from anaerobic digestion of organic waste [49]. It appears that currently bioreactor landfills do not deliver the promise of accelerated treatment but still produce undesirable toxic products such as landfill leachate and rank poorly in terms of environmental impact. Due to this and various other limitations mentioned above (such as higher moisture requirements, anaerobic environment, and lack of adequate mixing for transportation of microbes and substrates), the 
use of bio-landfilling has not served to improve the actual degradation of solid wastes substantially in full-scale applications [48], [50] and has not been adopted in NZ. However, bioremediation on a longer and larger scale may provide a sustainable solution for the treatment of CD\&E and associated hazardous wastes, providing public health and safety can be assured.

\subsubsection{Bioremediation}

Bioremediation utilises living organisms such as plants, microbes and their enzymatic products to reduce toxicity in xenobiotic compounds [51]. Microorganisms are versatile and are capable of rapid adjustment during environmental changes and can therefore serve to protect their ecosystems from deterioration. Microbial-mediated bioremediation is cost effective, sustainable and in-situ application is easily implemented. Either naturally occurring metabolic activity can be utilised during bioremediation for the degradation, transformation or accumulation of many substances [52] or microbial augmentation with non-native species can be effective [51]. Despite the perceived low potential for biological degradation of inorganic species (Fig. 1), successful steps towards bioremediation have been identified recently. For example, the bacterial bioremediation of metal-contaminated waste [51] and the successful use of bioremediation strategies for radionuclides [53], highlighting the potential for bioremediation [54].

Phytoremediation of acidic mining drainage in mine tailings has also shown plants to facilitate the immobilization of other heavy metals such as lead, cadmium, zinc, iron and nickel [55]. Phytocapping, (growth of plants over mine tailings), relies on the addition of an amendment layer on the mine tailings to enable plants to adapt to biotoxins and the acidic $\mathrm{pH}$ [55]. Similarly, in the potential bioremediation of other inorganic hazardous materials such as asbestos [56], these and other factors will need to be addressed, especially the lack of organic material and nutrients for growth present within pure asbestos deposits. Unless these can be sufficiently supplemented either by the managed ecosystem itself or the addition of carbon and nutrient rich amendments, bioremediation will be difficult to optimise.

Landfarming, an ex-situ bioremediation technology, is a contained, controlled degradation of contaminants in varied soil conditions to optimize the rate of degradation [57]. Contaminated waste is mixed with soil amendments such as soil bulking agents and/or nutrients then adjusted for parameters such as moisture, $\mathrm{pH}$ and aeration (by periodic tilling) [57], [58]. This allows the contaminants to interact with the soil and climate of the site to degrade, immobilize and transform contamination constituents [57]. Landfarming is proven to be most successful in treating petroleum hydrocarbons, and other more chlorinated or nitrated compounds albeit with more difficulty [58]. Potential environmental hazards from landfarming applications can arise from any residual toxic substances remaining within the soil profile; groundwater contamination (leaching); and airborne hazardous substances.

Disadvantages for the use of bioremediation include issues associated with accurate scaleup and a lack of standardised methods for measuring biodegradation rates, resulting in scarce data sets. The use of lab scale experiments to predict field scale results appears risky for determining treatment rates, and bacterial or plant-based processes may produce large volumes of pollutant-loaded biomass which can result in further waste disposal issues. However, the use of fungi for bioremediation processes may present greater opportunities, especially for hazardous substances. In the case of asbestos, the removal of iron from asbestos materials has been indicated using lichens and fungi where the degradation of asbestos using fungi has been tested in controlled laboratory studies [56], [59], [60]. To maximise the potential of bioremediation techniques whilst reducing risk, can the implementation of a solid waste treatment process provide a solution? 


\section{ADVANCED TREATMENT POTENTIAL}

Currently bioremediation provides a large-scale, long-term option for relatively slow microbial degradation of a wide variety of compounds requiring low energy and low-level maintenance (as demonstrated in Fig. 2). Timescales, process security and public safety may prevent this option providing a solution of CD\&E waste streams (particularly for hazardous wastes). Landfarming (a form of bioremediation which requires a higher level of engineering and maintenance than other forms of bioremediation) also shows promise but will require further adaptation to ensure public safety due to the tilling process to provide aeration. In terms of public health and safety, traditional landfills provide a high level of protection (in the short-term) due to their containment methods, however, their design accommodates low/no degradation of waste. In comparison bioreactor landfills have been designed to provide low level degradation and energy recovery potential, although these benefits come with management requirements. A major drawback to the use of bioremediation and landfarming, is the potential migration of very stable hazardous substances (e.g. asbestos), therefore containment to provide degradation is needed.

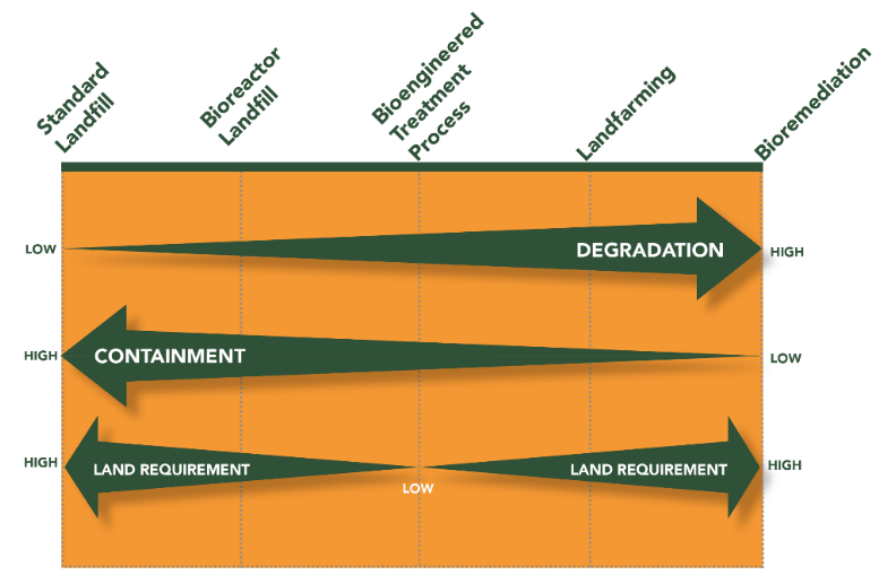

Figure 2: Disposal versus treatment in terms of microbial degradation, containment, land requirements.

In the centre of the two extremes (landfill versus bioremediation) lies the potential to create an engineered treatment process which could use aspects of current landfill design alongside optimised bioremediation (Bioengineered Treatment Process). This sustainable approach will require careful identification and separation of the waste types (Fig. 3), for which there must be a clear incentive. This process may require a pre-treatment stage and this should be followed by a well-managed waste process rather than a singular option of landfilling. Advantages of this type of process train may include:

- The creation of a less toxic environment due to the separation of hazardous substances could increase potential for microbial breakdown.

- A reduction in the creation of highly toxic hazardous mixtures which are difficult to manage in the event of an enclosure failure.

- The potential for reuse or recycling of hazardous substances (after processing), which completes the material loop, and is especially valuable for heavy metals. 


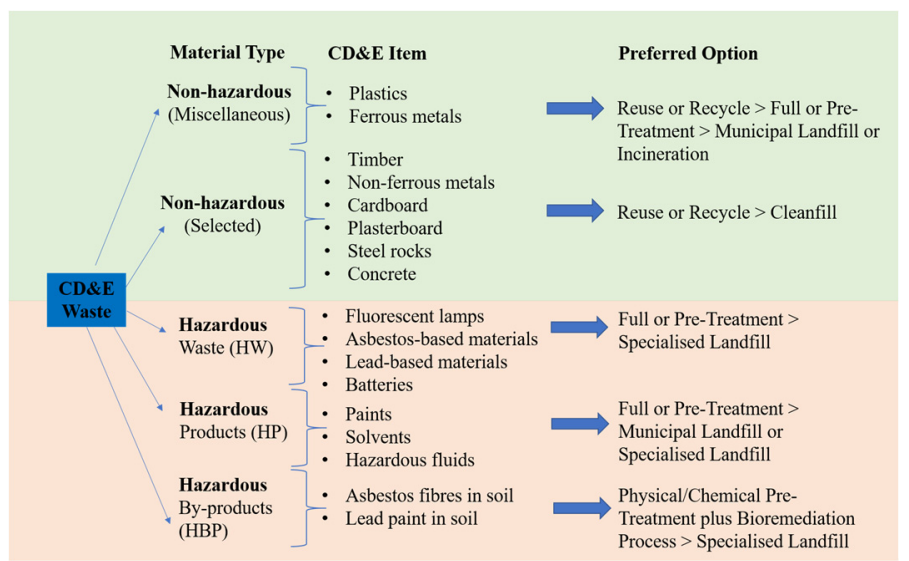

Figure 3: Defining and treating hazardous and non-hazardous CD\&E waste.

\section{CONCLUSIONS}

We already have well-established biological treatment processes for the water and wastewater industry including suspended and fixed growth microbial systems. Although these systems have developed significantly over the last few decades, similar investments and advancements for solid waste treatment processes have not been forthcoming. This may be due to high land space requirements, lack of incentives and perceived lack of feasibility. However, the main reason is that landfill processes are simple and low cost by comparison despite their shortcomings in terms of sustainability.

The proposed bioengineered treatment process aims to expand and adapt the methods for organic waste bioreactor (or activated) landfills incorporating the treatment processes utilized by bioremediation, to a landfill design suitable for the treatment of even hazardous CD\&E waste; to minimise risk to public but maximise treatment. We still need to be sure that short term risks are acceptable even though long-terms risks may be far better. For this purpose, knowledge about treatment options for organic and inorganic wastes must be combined in novel ways and assumptions tested. In the long-term, the development of multiple biotechnological processes (according to waste type) may provide a better and more sustainable solution to combined waste disposal in landfills.

\section{ACKNOWLEDGEMENT}

The authors would like to acknowledge the NZ Ministry for the Environment (MfE) Waste Minimisation Fund for part-funding this research.

\section{REFERENCES}

[1] Kaza, S., Yao, L., Bhada-Tata, P. \& Van Woerden, F., What a Waste 2.0: A Global Snapshot of Solid Waste Management to 2050, World Bank: Washington, DC, 2018.

[2] United Nations Environmental Programme (UNEP), Sustainable building and construction: Facts and figures. Industry and Environment - A Quarterly Review, United Nations Environmental Programme (April-September), Division of Technology, Industry and Economics, 26(2), pp. 5-98, 2003.

[3] Inglis, M., Construction and demolition waste: Best practice and cost saving. Proceedings of the New Zealand Sustainable Building Conference, 057, 2007. 
[4] Luangcharoenrat, C., Intrachooto, S., Peansupap, V. \& Sutthinarakorn, W., Factors influencing construction waste generation in building construction: Thailand's perspective. Sustainability, 11(13), 3638, 2019. https://doi.org/10.3390/su11133638.

[5] Department of Environmental Affairs, Republic of South Africa, South Africa State of Waste Report. http://sawic.environment.gov.za/documents/8641.pdf. Accessed on: 13 Jun. 2019.

[6] Department of Environment Food \& Rural Affairs, UK, UK statistics on waste. https://assets.publishing.service.gov.uk/government/uploads/system/uploads/ attachment_data/file/784263/UK_Statistics_on_Waste_statistical_notice_March_ 2019_rev_FINAL.pdf. Accessed on: 13 Jun. 2019.

[7] Federal Ministry for the Environment, Nature Conservation and Nuclear Safety, Germany, Waste management in Germany 2018. www.bmu.de/fileadmin/Daten BMU/Pools/Broschueren/abfallwirtschaft_2018_en_bf.pdf. Accessed on: 13 Jun. 2019.

[8] Blue Environment, National waste report 2018. Prepared for Australian Government, Department of the Environment and Energy. www.environment.gov.au/system/files/ resources/7381c1de-31d0-429b-912c-91a6dbc83af7/files/national-waste-report2018.pdf. Accessed on: 13 Jun. 2019.

[9] Eurostat, Waste statistics: Statistics explained. https://ec.europa.eu/eurostat/statisticsexplained/pdfscache/1183.pdf. Accessed on: 30 Jun. 2019.

[10] Yonetani, H., Construction and demolition waste management in Japan. www.uncrd.or.jp/content/documents/2661Parallel\%20Roundtable(2)-Presentation (4)-Hideko\%20Yonetani.pdf. Accessed on: 30 Jun. 2019.

[11] Ministry for the Environment (MfE) New Zealand, Module 1: Hazardous waste guidelines: Identification and record-keeping. www.mfe.govt.nz/sites/default/files/ hazardous-waste-module-1.pdf. Accessed on: 13 Feb. 2020.

[12] Boyle, C.A., Solid waste management in New Zealand. Waste Management, 20, pp. 517-526, 2000.

[13] Ministry for the Environment (MfE) New Zealand, The New Zealand waste strategy: Reducing harm, improving efficiency. www.mfe.govt.nz/sites/default/files/ wastestrategy.pdf. Accessed on. 12 Mar. 2020.

[14] PBC Today, Dealing with hazardous waste. www.pbctoday.co.uk/news/planningconstruction-news/hazardous-waste-construction/53765/. Accessed on: 16 Mar. 2020.

[15] Hyder Consulting, Encycle Consulting \& Sustainable Resource Solutions, Construction and demolition waste status report: Management of construction and demolition waste in Australia. www.environment.gov.au/system/files/resources/ 323e8f22-1a8a-4245-a09c-006644d3bd51/files/construction-waste.pdf. Accessed on: 9 Jul. 2019.

[16] Kumar, S., Chiemchaisri, C. \& Mudhoo, A., Bioreactor landfill technology in municipal solid waste treatment: An overview. Critical Reviews in Biotechnology, 31(1), pp. 77-97, 2011.

[17] Stats NZ, Measuring New Zealand's progress using a sustainable development approach, 2008: Topic 8: Waste. http://archive.stats.govt.nz/browse_for_stats/ snapshots-of-nz/Measuring-NZ-progress-sustainable-dev-\%20approach/sustainabledevelopment/waste.aspx\#. Accessed on: 18 Feb. 2020.

[18] Ministry for the Environment (MfE) New Zealand, Environment New Zealand 2007: Chapter 6: Waste. www.mfe.govt.nz/publications/environmental-reporting/ environment-new-zealand-2007/chapter-6-waste. Accessed on: 18 Feb. 2020. 
[19] Ministry for the Environment (MfE) New Zealand, Solid waste composition: Environmental report card July 2009. www.mfe.govt.nz/environmental-reporting/ waste/waste-composition-2009/index.html. Accessed on: 2 Mar. 2020.

[20] Ministry for the Environment (MfE) New Zealand, Types of landfills. www.mfe.govt.nz/waste/waste-guidance-and-technical-information/types-oflandfills. Accessed on: 18 Feb. 2020.

[21] Ministry for the Environment (MfE) New Zealand, Module 2: Hazardous waste guidelines - Landfill waste acceptance criteria and landfill classification. www.mfe.govt.nz/sites/default/files/haz-waste-guide-module-2-may04.pdf. Accessed on: 18 Feb. 2020.

[22] Auckland Council, Auckland's waste assessment 2017. www.aucklandcouncil.govt.nz/plans-projects-policies-reports-bylaws/our-plansstrategies/topic-based-plans-strategies/environmental-plans-strategies/ docswastemanagementplan/waste-assessment-2017.pdf. Accessed on: 30 Jun. 2019.

[23] Ministry for the Environment (MfE) New Zealand, Targets in the New Zealand waste strategy: 2006 review of progress. www.mfe.govt.nz/publications/waste/wastestrategy-review-progress-mar07/html/page5a.html\#figure14. Accessed on: 30 Jun. 2019.

[24] Carson, D.A., The municipal solid waste landfill operated as a bioreactor. Proceedings of the Landfill Bioreactor Design and Operation Conference, pp. 1-8, 1995.

[25] Centre for Advanced Engineering (CAE), Landfill guidelines: Towards sustainable waste management in New Zealand. www.mfe.govt.nz/sites/default/files/4139 landfill.pdf. Accessed on: 26 Feb. 2020.

[26] Waste Management Institute New Zealand (WasteMINZ), Technical guidelines for disposal to land. www.wasteminz.org.nz/wp-content/uploads/2016/04/TechnicalGuidelines-for-Disposal-to-Land-9Aug18-FINAL.pdf. Accessed on: 2 Mar. 2020.

[27] Zero Waste New Zealand, Waste opportunity: A closer look at landfilling and incineration. http://zerowaste.co.nz/assets/Wastedopportunities.pdf. Accessed: 5 Mar. 2020.

[28] Tohill, S., Personal communication, February 2020. New Zealand Demolition and Asbestos Association (NZDAA), New Zealand.

[29] Thom, N.G., Factors influencing the satisfactory disposal of special wastes. Transactions of the Institute of Professional Engineers New Zealand: Civil Engineering Section, 12(1), pp. 38-46, 1985.

[30] Miller, N., What can you do with a problem landfill? World Wastes, 39(2), p. 42, 1996.

[31] Merry, S.M., Kavanzanjian Jr., E. \& Fritz, W.U., Reconnaissance of the July 10, 2000, Payatas landfill failure. Journal of Performance of Constructed Facilities, 19(2), pp. 100-107, 2005.

[32] Lavigne, F. et al., The 21 February 2005 catastrophic waste avalanche at Leuwigajah dumpsite, Bandung, Indonesia. Geoenvironmental Disasters, 1(10), 2014.

https://doi.org/10.1186/s40677-014-0010-5.

[33] BBC News, Brazil landslide death toll rises. http://news.bbc.co.uk/2/hi/8612699.stm. Accessed on: 5 Mar. 2020.

[34] Petley, D., Garbage dump landslide in the Philippines. https://blogs.agu.org/landslideblog/2011/08/31/garbage-dump-landslide-in-thephilippines/. Accessed on: 5 Mar. 2020.

[35] Musulin, K., Collapse at Guatemala City's largest garbage dump leaves 4 dead, 24 missing. www.wastedive.com/news/collapse-at-guatemala-citys-largest-garbagedump-leaves-4-dead-24-missing/418454/. Accessed on: 5 Mar. 2020. 
[36] Petley, D., Koshe, Ethiopia: The worst garbage dump landslide in recent years. https://blogs.agu.org/landslideblog/2017/03/17/koshe-1/. Accessed on: 5 Mar. 2020.

[37] Daily Mirror, Meethotamulla tragedy. www.dailymirror.lk/article/Meethotamullatragedy--127303.html. Accessed on: 5 Mar. 2020.

[38] Sesay, I., Search for two people buried alive under landslide suspended due to asbestos fear. www.euroweeklynews.com/2020/02/07/breaking-update-search-for-two-peopleburied-alive-under-landslide-suspended-due-to-asbestos-fear/. Accessed on: 3 Mar. 2020.

[39] Ewing, I., Environmental catastrophe after West Coast storm exposes old landfill. www.newshub.co.nz/home/new-zealand/2019/04/environmental-catastrophe-afterwest-coast-storm-exposes-old-landfill.html. Accessed on: 14 Feb. 2020.

[40] NZ Herald, Fears sea will breach old landfill in Dunedin, creating rubbish disaster. www.nzherald.co.nz/index.cfm?objectid=12256976\&ref=twitter. Accessed on: 13 Feb. 2020.

[41] Carrington, D., Pollution risk from over 1,000 old UK landfill sites due to coastal erosion. www.theguardian.com/environment/2016/may/05/pollution-risk-from-over1000-landfill-sites-england-wales-coastal-erosion. Accessed on: 26 Feb. 2020.

[42] Wharton, J., Landfill site starts leaking plastic into the Thames. https://metro.co.uk/ 2019/11/06/landfill-site-starts-leaking-plastic-thames-11050538/. Accessed on: 26 Feb. 2020.

[43] 7News, Residents living above Melbourne's Sunshine Landfills potentially leaking toxic gas. https://7news.com.au/news/environment/residents-living-abovemelbournes-sunshine-landfills-potentially-leaking-toxic-gas-c-720854. Accessed on: 5 Mar. 2020.

[44] Davis, M.L. \& Cornwell, D.A., Introduction to Environmental Engineering, 5th ed., McGraw-Hill: New York, 2012.

[45] Spasiano, D., Dark fermentation process as pretreatment for a sustainable denaturation of asbestos containing wastes. Journal of Hazardous Materials, 349, pp. 45-50, 2018. https://doi.org/10.1016/j.jhazmat.2018.01.049.

[46] Vidali, M., Bioremediation: An overview. Pure Applied Chemistry, 73(7), pp. 11631172, 2001.

[47] Nishiwaki, J., Kawabe, Y., Komai, T. \& Zhang, M., Decomposition of gasoline hydrocarbons by natural microorganisms in Japanese soils. Geosciences, 8(2), p. 35, 2018. https://doi.org/10.3390/geosciences8020035.

[48] Tolaymat, T., Kim, H., Jain, P., Powell, J. \& Townsend, T., Moisture addition requirements for bioreactor landfills. Journal of Hazardous, Toxic, and Radioactive Waste, 17(4), pp. 360-364, 2013.

[49] Arafat, H.A., Jijakli, K. \& Amimul, A., Environmental performance and energy recovery potential of five processes for municipal solid waste treatment. Journal of Cleaner Production, 105, pp. 233-240, 2015.

[50] Blackburn, J.W., Bioremediation scale-up effectiveness: A review. Bioremediation, 1(4), pp. 265-282, 1998.

[51] Das, S. \& Dash, H.R., Microbial bioremediation: A potential tool for restoration of contaminated areas. Microbial Biodegradation and Bioremediation, ed. S. Das, Elsevier Insights: USA, pp. 1-21, 2014.

[52] Karigar, C.S. \& Rao, S.S., Role of microbial enzymes in the bioremediation of pollutants: A review. Enzyme Research, 2011. https://doi.org/10.4061/2011/805187. 
[53] Sanchez-Castro, I. et al., Screening of bacterial strains isolated from uranium mill tailing porewaters for bioremediation purposes. Journal of Environmental Radioactivity, 166, pp. 130-141, 2017. https://doi.org/10.1016/j.jenvrad.2016.03.016.

[54] Merroun, M.L. \& Selenska-Pobell, S., Bacterial interactions with uranium: An environmental perspective. Journal of Contaminant Hydrology, 102(3/4), pp. 285295, 2008. https://doi.org/10.1016/j.jconhyd.2008.09.019.

[55] Karaca, O., Camaselle, C. \& Reddy, K.R., Mine tailing disposal sites: Contamination problems, remedial options and phytocaps for sustainable remediation. Reviews in Environmental Science and Biotechnology, 17(1), pp. 205-228, 2017. https://doi.org/10.1007/s11157-017-9453-y.

[56] Wallis, S.L. et al., Challenging global waste management: Bioremediation to detoxify asbestos. Frontiers in Environmental Science, 8(20), pp. 1-14, 2020. https://doi.org/10.3389/fenvs.2020.00020.

[57] Federal Remediation Technologies Roundtable (FRDF), Remediation technologies screening matrix and reference guide, Version 4.0, 4.13 Landfarming. https://frtr.gov/matrix2/section4/4_13a.html. Accessed on: 20 Nov. 2019.

[58] Center for Public Environmental Ōversight (CPEO), Landfarming. www.cpeo.org/techtree/ttdescript/lanfarm.htm. Accessed on: 20 Nov. 2019.

[59] Daghino, S., Martino, E., Fengolio, I., Tomatis, M., Perotto, S. \& Fubini, B., Inorganic materials and living organisms: Surface modifications and fungal responses to various asbestos forms. Chemistry, 11(19), pp. 5611-5618, 2005. https://doi.org/10.1002/chem.200500046.

[60] Daghino, S. et al., Bioweathering of chrysotile by fungi isolated in ophiolitic sites. FEMS Microbiology Letters, 285(2), pp. 242-249, 2008. https://doi.org/10.1111/j.1574-6968.2008.01239.x. 